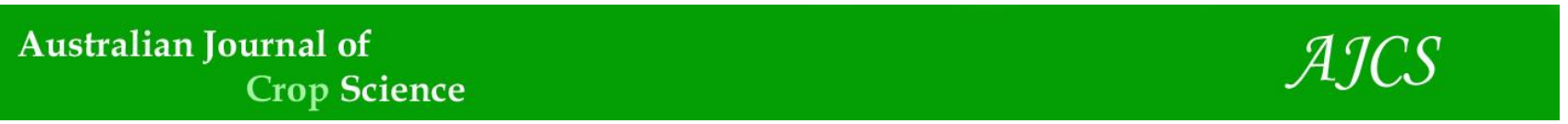

AJCS 14(11):1748-1755 (2020)

ISSN:1835-2707

doi: 10.21475/ajcs.20.14.11.p2471

\title{
Effect of water salinity and potassium doses on physiological traits and growth of 'Embrapa 51' precocious dwarf cashew (Anacardium occidentale L.) rootstock
}

\author{
Geovani Soares de Lima ${ }^{1}$, Jailson Batista da Silva ${ }^{1}$, Lauriane Almeida dos Anjos Soares, Reginaldo Gomes \\ Nobre $^{2}$, Hans Raj Gheyi ${ }^{3}$, Genilson Lima Diniz ${ }^{1}$, Pedro Dantas Fernandes ${ }^{4}$, Jussara Silva Dantas ${ }^{1}$, Vera Lúcia \\ Antunes de Lima ${ }^{4}$
}

\author{
${ }^{1}$ Federal University of Campina Grande, Academic Unit of Agrarian Sciences, Pombal, 58.840-000, Paraíba, Brazil \\ ${ }^{2}$ Federal Rural University of the Semi-arid Region, Department of Science and Technology, Caraúbas, 59.780-000, \\ Rio Grande do Norte, Brazil \\ ${ }^{3}$ Federal University of Recôncavo of Bahia, Nucleus of Soil and Water Engineering, Cruz das Almas, 44.380-000, \\ Bahia, Brazil \\ ${ }^{4}$ Federal University of Campina Grande, Academic Unit of Agricultural Engineering, Campina Grande, 58.109-970, \\ Paraíba, Brazil
}

*Corresponding author: geovanisoareslima@gmail.com

\begin{abstract}
In the semiarid regions, plants are constantly exposed to different conditions of abiotic stresses due to the occurrence of excess salts in both soil and water. Thus, it is extremely important to identify an alternative capable of minimizing the effects of salt stress on plants as a way to ensure the expansion of irrigated areas. In this context, this study aimed to evaluate the chloroplast pigments, photochemical efficiency and growth of 'Embrapa 51' precocious dwarf cashew as a function of irrigation with saline water and potassium fertilization in the rootstock formation stage. The study was conducted under greenhouse conditions in the municipality of Pombal, PB, Brazil, using a randomized block design in a $5 \times 2$ factorial scheme, corresponding to five levels of irrigation water electrical conductivity - ECW $\left(0.4 ; 1.2 ; 2.0 ; 2.8\right.$ and $\left.3.6 \mathrm{dS} \mathrm{m}^{-1}\right)$ and two doses of potassium fertilization - KD (100 and $150 \%$ of the recommendation corresponding to 150 and $225 \mathrm{~g} \mathrm{~K}_{2} \mathrm{O} \mathrm{kg}$ soil), with two plants per plot and three replicates. Water salinity from 0.4 induced reductions in chlorophyll $a$ and $b$ synthesis, maximum and variable fluorescence and growth in sexually propagated precocious dwarf cashew seedlings and increases in carotenoid content and initial chlorophyll fluorescence. The quantum efficiency of photosystem II in cashew plants was decreased sharply with the increment in water salinity levels, standing out as indicative of damage to the photosystem II reaction centres. 'Embrapa 51' precocious dwarf cashew plants can be classified as sensitive to water salinity above $0.4 \mathrm{dS} \mathrm{m}^{-1}$. Potassium doses of 100 and $150 \%$ of the recommendation did not alleviate the effects of salt stress during the precocious dwarf cashew rootstock production phase.
\end{abstract}

Keywords: Anacardium occidentale L.; salt stress; fertilization.

Abbreviations: Fo_initial fluorescence, Fv_variable fluorescence, Fm_maximum fluorescence, ФPSII_quantum efficiency of photosystem II, $\mathrm{Chl} a \_C h l o r o p h y l l ~ a, \mathrm{Chl} b \_$Chlorophyll $b, \mathrm{ECw}$ irrigation water electrical conductivity, KD_potassium fertilization, PH_plant height, SD_stem diameter, LA_leaf area, DAS_days after sowing, FM_fresh matter.

Introduction

Cashew cultivation is one of the main socioeconomic activities conducted in the semiarid region of Northeastern Brazil, presenting itself as an important alternative to generate employment and income (Araújo et al., 2014). It is a fruit crop that can grow well in semiarid environments and stands out for the high potential both for the fresh consumption of its pseudofruit and in the nut industry. It can be used to obtain various products such as juices, soft drinks, candies, jams, nectars, flours and alcoholic beverages (Rabbani et al., 2012).

The precocious dwarf cashew plant differs from common cashew (or Giant cashew tree) due to its small size, height less than $4 \mathrm{~m}$, homogeneous crown, smaller stem diameter and crown span compared to the common type, precocious cycle, beginning the flowering between 6 and 18 months
(Oliveira, 2008). Among the commonly used clones, the Embrapa 51 clone stands out for its small size, average height of $3.52 \mathrm{~m}$ at the sixth year of age, average crown diameter of $7.79 \mathrm{~m}$, nut weight of $10.4 \mathrm{~g}$, kernel/shell ratio of $24.5 \%$, kernel weight of $2.6 \mathrm{~g}$, resistance to anthracnose and moderate resistance to black mould (Diplodium anacardiacearum) (Barros et al., 2000).

In this region, salinity is one of the abiotic stresses that most limit crop establishment (Amorim et al., 2010), affecting almost all aspects of plant development, including: emergence, vegetative growth and reproductive development. Excess salts impose ionic toxicity, osmotic stress, nutrient deficiency and oxidative stress on plants (Shrivastava et al., 2015) due to overproduction of reactive oxygen species (ROS), such as singlet oxygen $\left({ }^{1} \mathrm{O}_{2}\right)$, hydroxyl 
radical ( $\left.{ }^{\circ} \mathrm{OH}\right)$, superoxide anion $\left(\mathrm{O}_{2}^{\circ}{ }^{\circ}\right)$ and hydrogen peroxide $\left(\mathrm{H}_{2} \mathrm{O}_{2}\right)$. ROS formation as a result of salt stress causes oxidative damage to lipids, proteins and other cellular components (Santos et al., 2018).

Salinity causes both osmotic and water stresses, reduction in leaf turgor, leading to stomatal closure and decrease in stomatal conductance, besides reduced content of photosynthetic pigments, inhibition of electron transport chain, disorganization of photosystem II complex (PSII), increase in non-photochemical quenching and alteration in the membrane structure (Hniličková et al., 2017). Thus, damage at any level caused by salt stress can reduce the photosynthetic capacity of the plants (Shraf and Harris, 2013).

An alternative that can reduce the effect of salt stress on cashew is the establishment of osmotic and ionic homeostasis through the supply of potassium, because the influx of $\mathrm{Na}^{+}$in plants occurs through the system of absorption of low- and high-affinity $\mathrm{K}^{+}$(Viégas et al., 2001). The positive regulation of $K$ status in the plant reduces ROS production, due to the activity of enzymes involved in ROS detoxification (Cakmak, 2005). In addition, it performs vital regulatory functions in biochemical and physiological processes that contribute to plant growth and development (Hasanuzzaman et al., 2018). Potassium plays a fundamental role in cell osmoregulation: its ions are necessary to retain the $\mathrm{pH}$ gradient through the thylakoid membrane. In photosynthesis, potassium acts in the activation of numerous enzymes and in the synthesis of ATP (Kalaji et al., 2016).

Considering that the expansion in the cultivation of this fruit crop in the semiarid region of Northeastern Brazil is conditioned on the use of salt stress-tolerant clones of precocious dwarf cashew, this study aimed to evaluate the chloroplast pigments, photochemical efficiency and growth of 'Embrapa 51' precocious dwarf cashew as a function of irrigation with saline water and potassium fertilization, in the rootstock formation stage.

\section{Results and discussion}

Effect of salt stress and potassium doses on chloroplast pigments of precocious dwarf cashew

The increasing levels of irrigation water salinity inhibited the chlorophyll $a$ synthesis of precocious dwarf cashew plants, at 75 days after sowing. The regression equation (Fig 1A) shows that the increase in electrical conductivity of water resulted in a linear reduction of $17.10 \%$ in $\mathrm{Chl} a$ content per unit increase of ECW. There was a relative reduction in $\mathrm{Chl} a$ contents of $4.87 \mathrm{mg} \mathrm{g}^{-1} \mathrm{FM}$ between plants cultivated under water salinity of $3.6 \mathrm{dS} \mathrm{m}^{-1}$ and those under the lowest ECW level $\left(0.4 \mathrm{dS} \mathrm{m}^{-1}\right)$. The reduction in chlorophyll $a$ content in response to salt stress occurs as a result of increased degradation through the enzyme chlorophyllase or inhibition of its synthesis. In addition, it may be associated with the decrease in the number of chloroplasts, which also affects the thylakoid membranes and plastids through their degradation (Mostajeran et al., 2014). According to Taibi et al. (2016), the reduction in chlorophyll $a$ contents in plants under salt stress has been considered a typical symptom of oxidative stress. In a study with West Indian cherry under salt stress conditions ( $\mathrm{ECW}$ of 0.8 and $3.8 \mathrm{dS} \mathrm{m}^{-1}$ ), Lima et al. (2018) also found that the chlorophyll $a$ content was markedly reduced with the increase in irrigation water salinity.
The chlorophyll $b$ contents of the cashew plants were also linearly reduced by water salinity and, according to the regression equation (Fig 1B), there was a reduction of $17.60 \%$ per unit increase in ECW. It is observed that the stress caused by irrigation using water of highest salinity level $\left(3.6 \mathrm{dS} \mathrm{m}^{-1}\right)$ caused a $60.60 \%$ reduction $\left(5.09 \mathrm{mg} \mathrm{g}^{-1}\right.$ $\mathrm{FM}$ ) in the $\mathrm{Chl} b$ contents compared to plants irrigated under electrical conductivity of $0.4 \mathrm{dS} \mathrm{m}^{-1}$. The reduction in chlorophyll $b$ content in cashew is possibly associated with the inhibition in the synthesis of 5-aminolevulin acid (chlorophyll precursor molecule) and with damage caused by salt stress, besides the formation of reactive oxygen species (ROS), which induce photo-oxidation of the pigments and degradation of chlorophyll molecules (Silva et al. 2016). A fact that may also be related to the sensitivity of the membranes to oxidative stress (Nedjimi, 2014).

The synthesis of carotenoids in precocious dwarf cashew plants (Fig 1C) was increased linearly in response to the increasing levels of water salinity, by $20.28 \%$ per unit increment in $\mathrm{ECW}$. In relative terms, there was an increase of $3.78 \mathrm{mg} \mathrm{g}^{-1} \mathrm{FM}(60.03 \%)$ in plants subjected to the highest ECW level $\left(3.6 \mathrm{dS} \mathrm{m}^{-1}\right)$ compared to those receiving water of

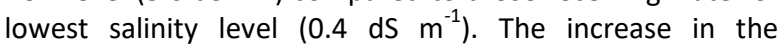
synthesis of carotenoids in plants under salt stress can be considered a tolerance mechanism. Because these are accessory pigments in the absorption and dissipation, in the form of heat and/or fluorescence and energy from the light photons captured by the pigments, which protect chlorophyll from photo-oxidation (Nascimento et al., 2015). In addition, carotenoids are pigments that can also act as antioxidants, protecting lipids of the plasmatic membrane from oxidative stress caused in plants exposed to salinity (Falk and Munné-Bosch, 2010). Unlike the data obtained in this study, Silva et al. (2017) evaluated the effects of water salinity ( $E C W$ ranging from 0.5 to $3.5 \mathrm{dS} \mathrm{m}^{-1}$ ) in soursop plants at 110 days after sowing and observed reduction in the synthesis of carotenoids as a function of salt stress. The above-mentioned authors attributed the decrease in the synthesis of carotenoids to damage the photosynthetic apparatus resulting from salt stress.

\section{Effect of salt stress and potassium doses on photochemical efficiency of precocious dwarf cashew}

The initial chlorophyll fluorescence increased linearly as the water salinity levels increased. It is possible to observe by the regression equation (Fig $2 \mathrm{~A}$ ) that an increase of $8.88 \%$ in initial fluorescence (Fo) may occur per unit increment of ECW. There was an increment of 232.56 between cashew plants subjected to ECW of $3.6 \mathrm{dS} \mathrm{m}^{-1}$ and those that received the water of lowest salinity $\left(0.4 \mathrm{dS} \mathrm{m^{-1 }}\right)$. The increase of initial fluorescence (Fo) in cashew plants as a function of $\mathrm{ECW}$ levels is an indication of damage and inactivation of the PSII reaction centres (Mehta et al., 2010). Moreover, such an increase may be related to the reduction in the capacity to transfer the excitation energy from the antenna to the reaction centre (Baker, 2008). According to Yamane et al. (2008), the increase of Fo in plants cultivated under abiotic stresses, such as salt stress, may be associated with increased leaf thickness due to lipid peroxidation caused by ROS. Dias et al. (2018), studied 'BRS 366 Jaburu' West Indian cherry cultivated under irrigation with saline waters (ECW: 0.8 and $3.8 \mathrm{dS} \mathrm{m}^{-1}$ ) and concluded that salt stress causes reduction in Fo, due to the damage caused by excess salts to chlorophyll $a$. 

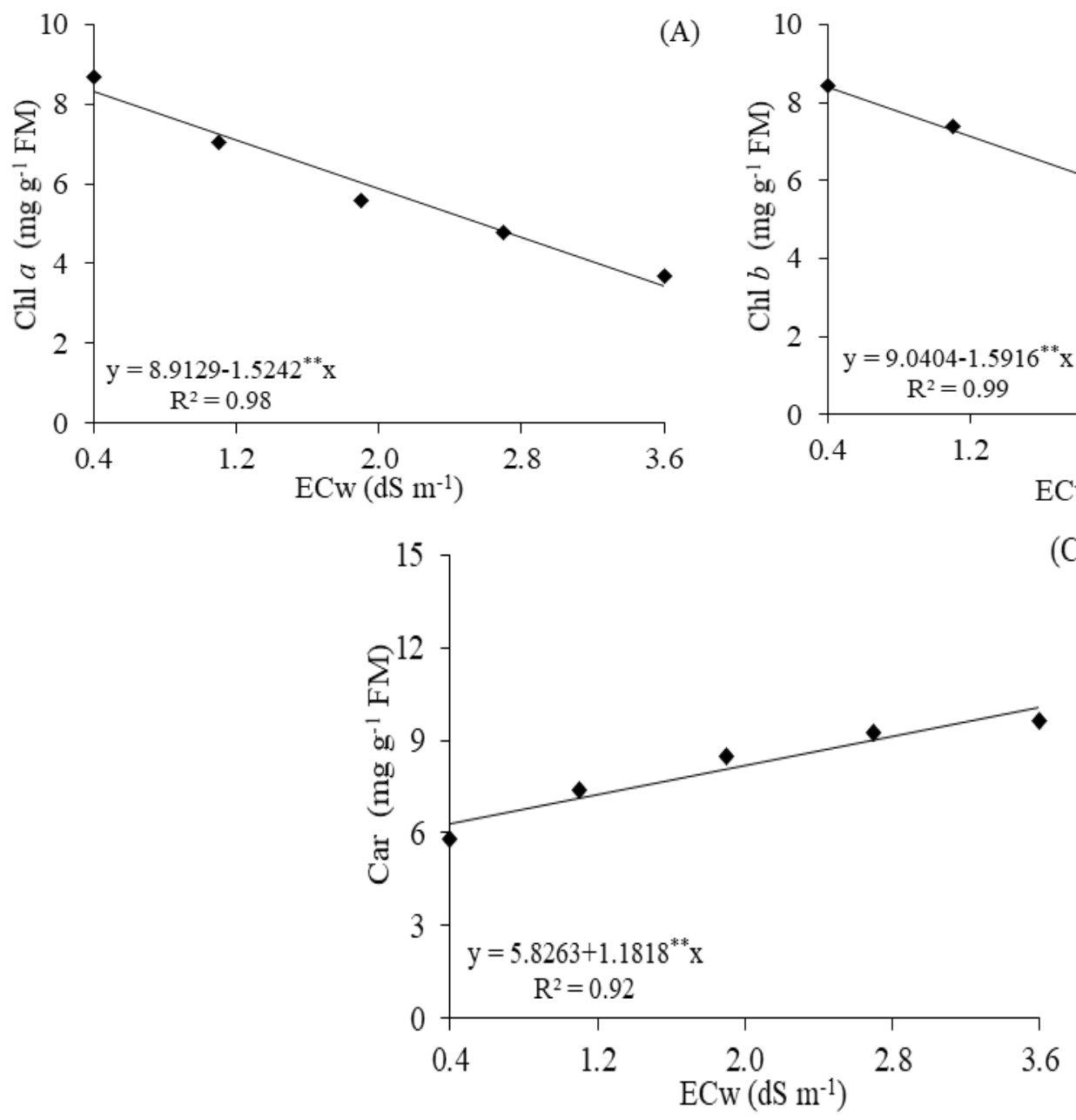

(B)

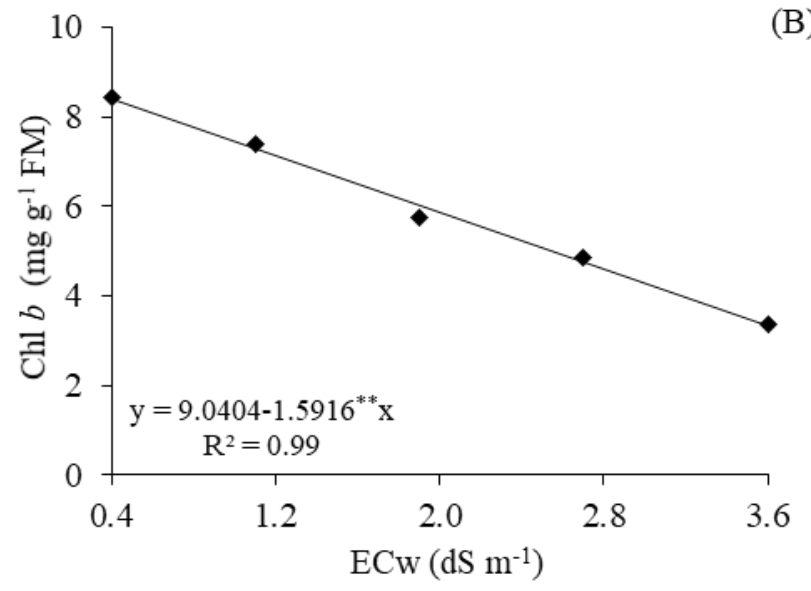

(C)

Fig 1. Contents of chlorophyll $a-\mathrm{Chl} a(\mathrm{~A})$, chlorophyll $b-\mathrm{Chl} b$ (B) and carotenoids - Car (C) of 'Embrapa 51' precocious dwarf cashew plants, as a function of water salinity $-\mathrm{ECW}$, at 75 days after sowing. ${ }^{* *}$, significant at $\mathrm{p}<0.01$.
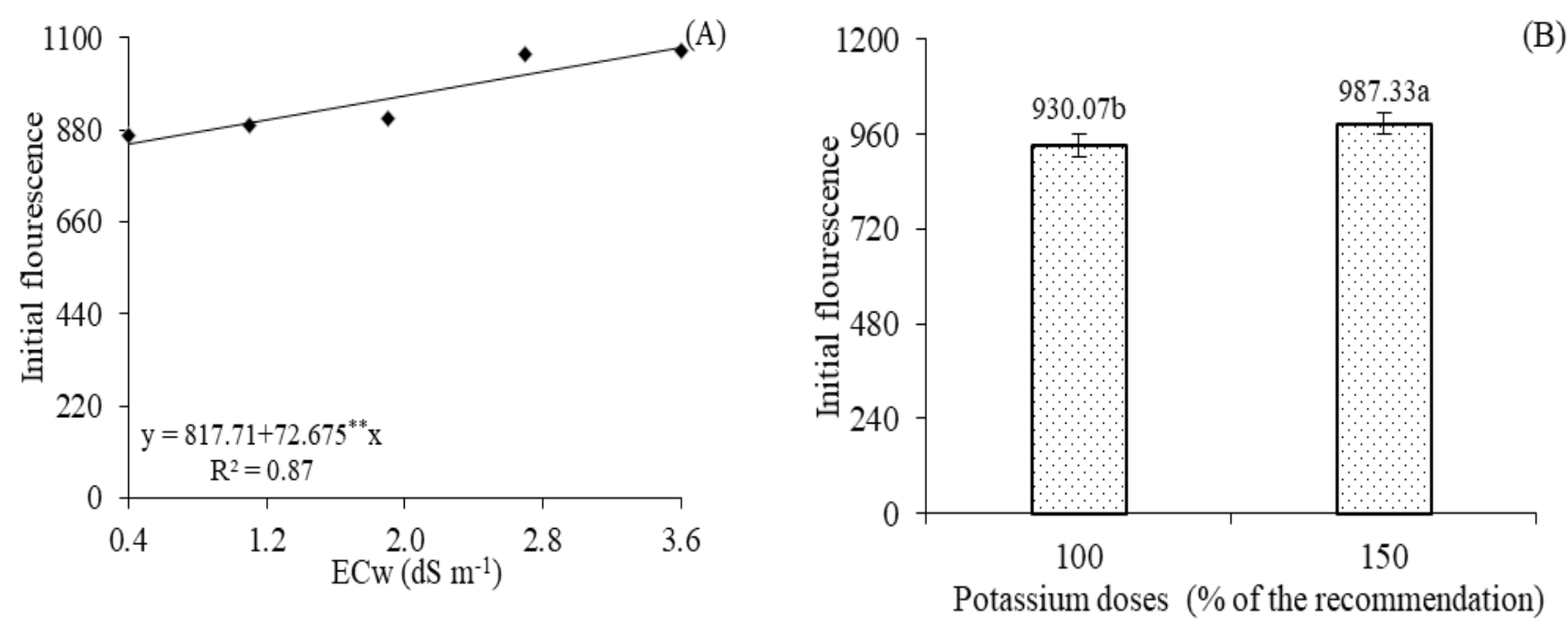

Fig 2. Initial fluorescence of 'Embrapa 51' precocious dwarf cashew plants as a function of water salinity - ECW (A) and potassium doses (B), at 75 days after sowing. Means followed by different letter indicate that the treatments differ by Tukey test, $p<0.05$. ${ }^{* *}$, significant at $p<0.01$; Bars represent the standard error of the mean $(n=3)$. 

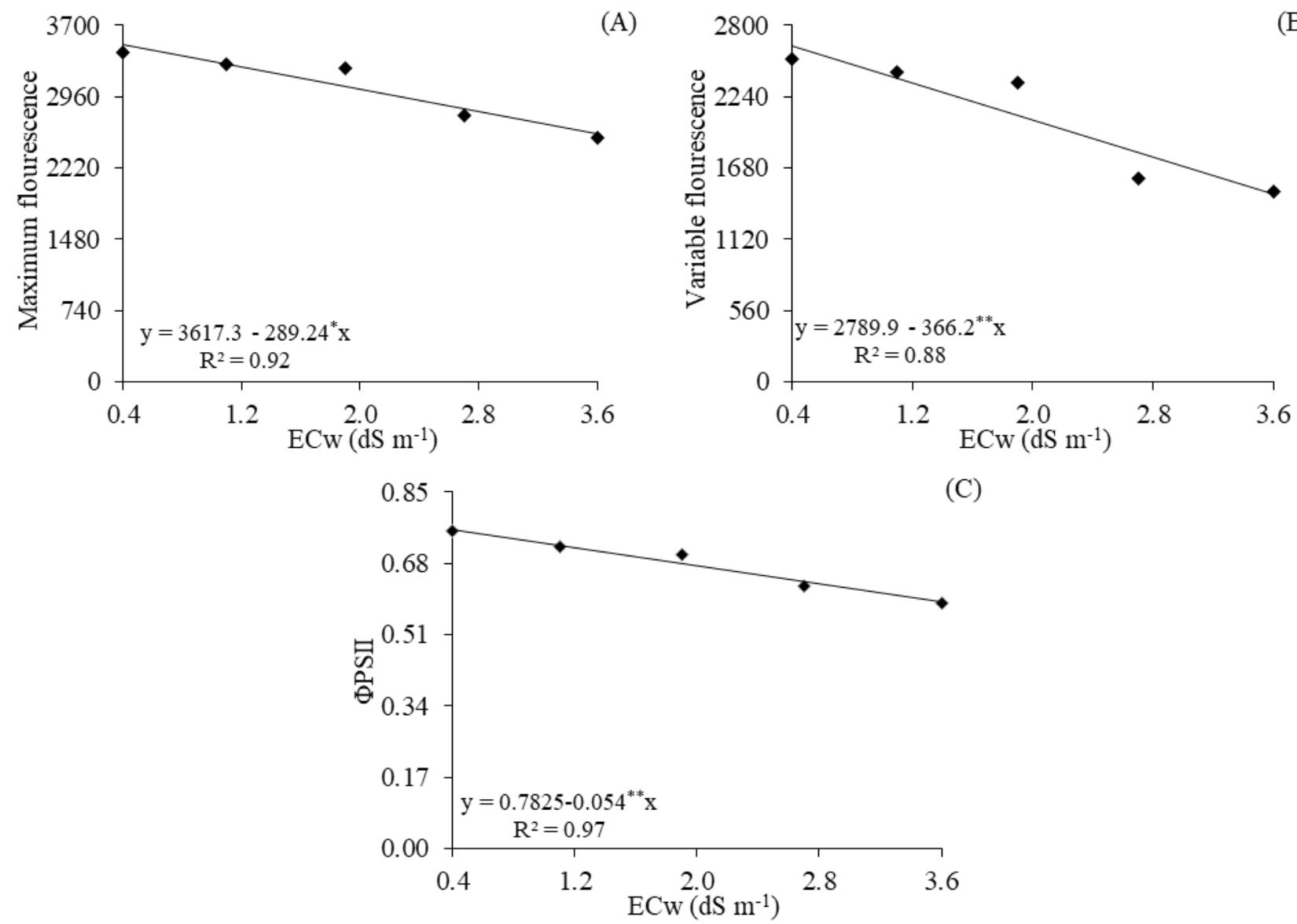

(C)

Fig 3. Maximum fluorescence (A), variable fluorescence (B) and quantum efficiency of photosystem II - ФPSII (C) of 'Embrapa 51' precocious dwarf cashew plants as a function of water salinity - ECW (A) and potassium doses (B), at 75 days after the sowing. ${ }^{* *}$, significant at $p<0.01$.

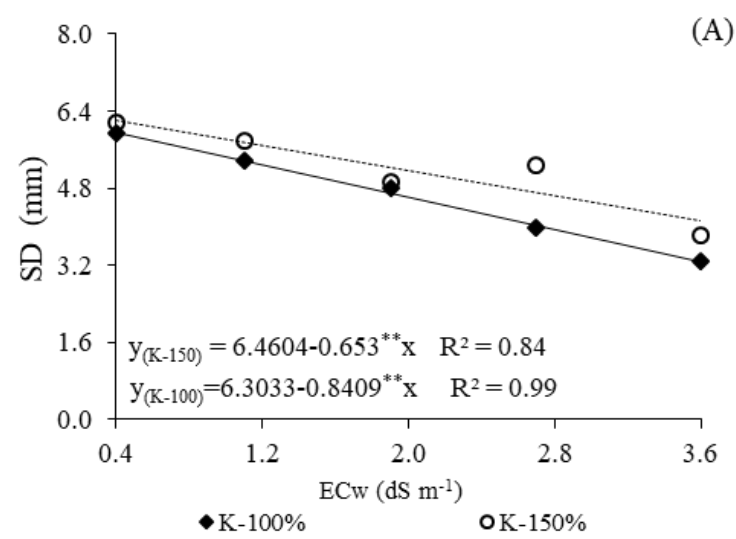

$\bullet \mathrm{K}-100 \% \quad$ OK- $150 \%$

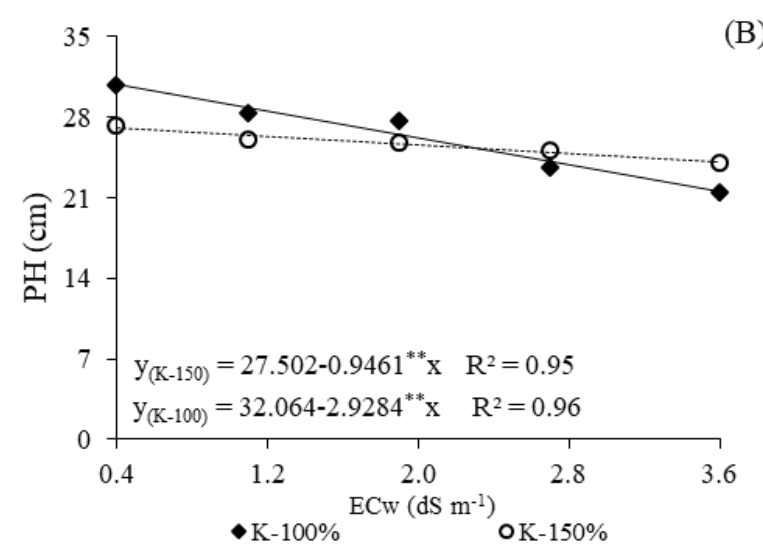

(C)

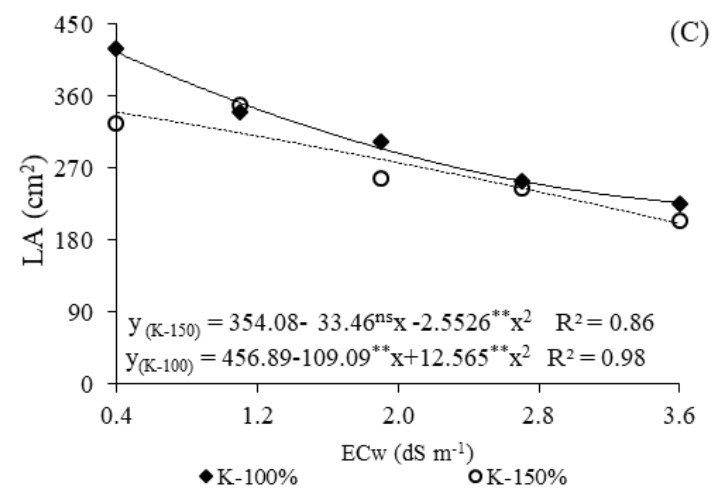

Fig 4. Stem diameter - SD (A), plant height - PH (B) and leaf area - LA (C) of 'Embrapa 51' precocious dwarf cashew plants as a function of the interaction between water salinity - ECW and potassium doses (A), at 25 days after sowing (DAS). ns, **, * Respectively, not significant, significant at $p<0.01$ and significant at $p<0.05$. 

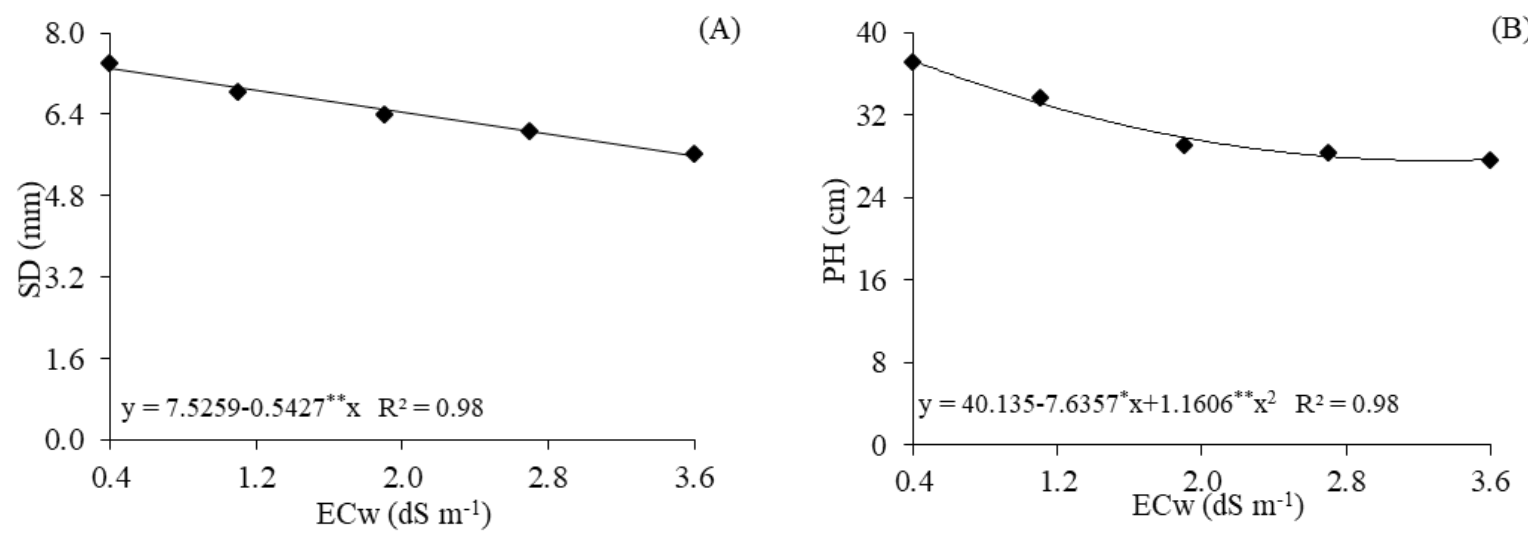

(B)

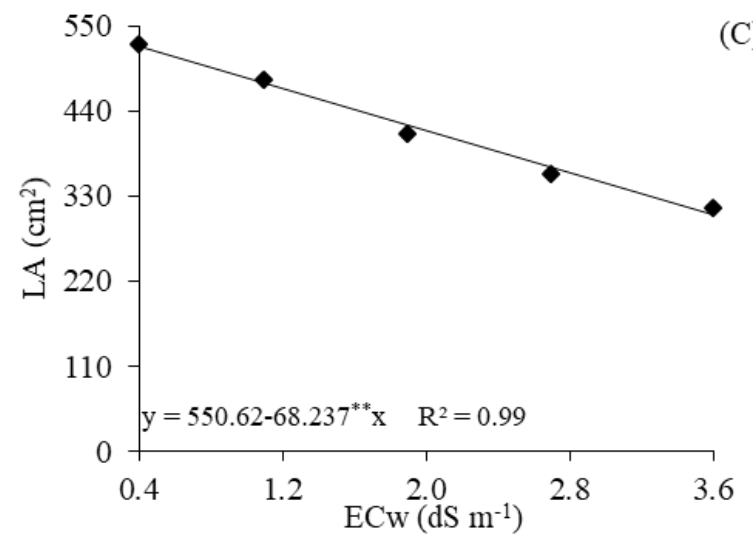

Fig 5. Stem diameter - SD (A), plant height - PH (B) and leaf area - LA (C) of 'Embrapa 51' precocious dwarf cashew plants as a function of water salinity - ECW, at 75 days after sowing (DAS). ${ }^{* *},{ }^{*}$ Respectively, significant at $p<0.01$ and $p<0.05$.

The initial fluorescence of precocious dwarf cashew was significantly influenced by potassium fertilization and, according to the means comparison test (Fig 2B), plants subjected to fertilization with $150 \%$ of the $\mathrm{K}$ recommendation had higher initial fluorescence (57.26), compared to plants that received $100 \%$. Dias et al. (2018), evaluated the effects of salt stress on the photochemical efficiency of West Indian cherry and did not observe significant effect of potassium doses (KD ranging from 50 to $125 \%$ of the recommendation) on the initial fluorescence of chlorophyll.

Maximum fluorescence represents the maximum intensity of fluorescence, when virtually all the quinone is reduced and the reaction centres reach their maximum capacity of photochemical reactions (Monteiro et al., 2018). According to the regression equation (Fig $3 \mathrm{~A}$ ), Fm decreased linearly by 7.99\% per unit increment in water electrical conductivity, i.e., plants under irrigation with $\mathrm{ECW}$ of $3.6 \mathrm{dS} \mathrm{m}^{-1}$ had $\mathrm{Fm}$ reduced by 925.56 , compared to those cultivated under the lowest salinity $\left(0.4 \mathrm{dS} \mathrm{m}^{-1}\right)$. Thus, the lower values of $\mathrm{Fm}$ obtained in plants under irrigation with saline waters is indication of a deficiency in the reduction of quinone $A$ in thylakoid membranes and in the electron flux between the photosystems (Tatagiba et al., 2014).

For Fv (Fig 3B), it was observed that the use of water with electrical conductivity of $3.6 \mathrm{dS} \mathrm{m}^{-1}$ caused a reduction of $13.12 \%$ per unit increment of ECW. By comparing the Fv of plants irrigated with $\mathrm{ECW}$ of $3.6 \mathrm{dS} \mathrm{m}^{-1}$ with that of plants cultivated under $0.4 \mathrm{dS} \mathrm{m}^{-1}$ water, it was possible to note a reduction of $44.33 \%$. The reduction of variable fluorescence is due to the decrease in chlorophyll contents (Melo et al.,
2017), which results in the loss of plant capacity to transfer the energy of the ejected electrons from the pigment molecules to the formation of the reducing agent NADPH, ATP and Fdr, leading to lower $\mathrm{CO}_{2}$ assimilation capacity in the biochemical phase of photosynthesis, hence causing reduction of growth (Baker, 2008; Silva et al., 2017). Reduction in Fv due to the use of saline water has been observed in studies conducted by Silva et al. (2017) with soursop and by Monteiro et al. (2018) with sweet sorghum. The quantum efficiency of photosystem II in cashew plants decreased linearly under salt stress. According to the regression equation (Fig $3 \mathrm{C}$ ), there were reductions of $6.90 \%$ per unit increase in $\mathrm{ECW}$. There was a reduction of $22.70 \%$ in ФPSII between plants cultivated under ECW of $3.6 \mathrm{dS} \mathrm{m}^{-1}$ and those subjected to the lowest level of electrical conductivity $\left(0.4 \mathrm{dS} \mathrm{m}^{-1}\right)$. Thus, the low values of ФPSII indicates that part of the PSII reaction centres is damaged or photochemically inactive, thus reducing the electron transport capacity in PSII, a phenomenon commonly observed in plants under stress (Hniličková et al., 2017). Decrease in the quantum efficiency of photosystem II in plants due to the imposition of salt stress has also been observed in other crops, such as soursop (Silva et al., 2017) and West Indian cherry (Dias et al., 2018).

Effect of salt stress and potassium doses on growth of precocious dwarf cashew

The growth in stem diameter, plant height and leaf area of 'Embrapa 51' cashew, at 25 days after sowing, was significantly influenced by the interaction between factors 
(SL x KD). SD and PH were decreased linearly, regardless of the $K$ dose applied. According to the regression equations (Fig 4A and 4B), there were decreases per unit increase in ECW of 10.10 and $13.34 \%$ in SD and of 3.44 and $9.13 \%$ in PH of plants fertilized with 100 and $150 \%$ of the $K$ recommendation, respectively. In relation to leaf area (Fig $4 C)$, a quadratic model fitted to the data of plants fertilized with 100 and $150 \%$ of the $K$ recommendation, with maximum values of 415.56 and $340.28 \mathrm{~cm}^{2}$ obtained the lowest level of ECW $\left(0.4 \mathrm{dS} \mathrm{m}^{-1}\right)$ and the minimum values of 223.77 and $190.07 \mathrm{~cm}^{2}$ obtained in plants under the highest level of water salinity $\left(3.6 \mathrm{dS} \mathrm{m}^{-1}\right)$. The reduction of stem diameter, plant height and leaf area in cashew plants is probably related to competition of $\mathrm{K}$ in the absorption of $\mathrm{Ca}^{2+}$ and $\mathrm{Mg}^{2+}$ because, during the absorption process by roots, these nutrients use the same transport sites (Malavolta et al., 1997).

Andriolo et al. (2010), studied the effect of potassium applied via fertigation and in the aerial part (leaves) of strawberry, also found that high $\mathrm{K}$ doses resulted in a reduction of plant growth. These authors attributed the negative effect of high $\mathrm{K}$ concentration on plant growth to the competitive absorption in relation to the total sum of cations within the plant, inducing calcium and magnesium deficiencies.

At 75 days after sowing, the growth in stem diameter, plant height and leaf area was also negatively affected by the increasing levels of water salinity. According to the regression equations (Fig 5), stem diameter and leaf area were decreased linearly by 7.21 and $12.39 \%$, respectively, per unit increase of water salinity. By comparing the SD and $\mathrm{PH}$ of plants cultivated under ECW of $3.6 \mathrm{dS} \mathrm{m}^{-1}$ to those of plants subjected to the lowest level of salinity $\left(0.4 \mathrm{dS} \mathrm{m}^{-1}\right)$, we observed reductions of $1.73 \mathrm{~mm}$ and $218.35 \mathrm{~cm}^{2}$, respectively. Regarding to plant height (Fig $5 \mathrm{~B}$ ), a quadratic model fitted to the data, and a maximum value of $37.26 \mathrm{~cm}$ was obtained in plants subjected to ECw level of $0.4 \mathrm{dS} \mathrm{m}^{-1}$, decreasing from this level and reaching the lowest $\mathrm{PH}$ value of $27.87 \mathrm{~cm}$ at the highest level of salinity $\left(E C W=3.6 \mathrm{dS} \mathrm{m}^{-1}\right)$. The reduction in the growth of cashew plants can be attributed to the inhibition of the synthesis of photosynthetic pigments imposed by the increasing levels of salinity, since chlorophyll is part of the light-harvesting antenna complex for the photosynthetic process (Tatagiba et al., 2014). According to Pak et al. (2009), the reduction in DPSII is one of the main factors responsible for the drastic decrease in the photosynthetic rate, and consequently, in the growth of plants cultivated under salt stress. Shah et al. (2018), evaluated the effects of irrigation with saline water ( $\mathrm{ECW}$ from 0.3 to $3.1 \mathrm{dS} \mathrm{m}^{-1}$ ) on the growth of 'Faga 11' precocious dwarf cashew. They found that stem diameter, plant height and leaf area were markedly reduced by the increase in water salinity.

\section{Materials and methods}

\section{Experiment location, procedure and treatments}

The study was conducted from August to October 2018 in plastic containers under greenhouse conditions, at the Centre of Science and Agri-Food Technology of the Federal University of Campina Grande (CCTA/UFCG), in the municipality of Pombal, PB, Brazil, located at the geographic coordinates $6048^{\prime} 16^{\prime \prime} \mathrm{S}$ latitude, 370 49' 15" W longitude and mean altitude of $175 \mathrm{~m}$.
The treatments resulted from the combination of five levels of irrigation water electrical conductivity $(0.4 ; 1.2 ; 2.0 ; 2.8$ and $3.6 \mathrm{dS} \mathrm{m}^{-1}$ ) associated with two doses of potassium fertilization - KD [100 and 150\% of the recommendation, according to Novais et al. (1991). The experimental design was randomized blocks in a $5 \times 2$ factorial arrangement, with two plants per plot and three replicates. The dose is referring to $100 \%$ corresponded to $150 \mathrm{mg}$ of $\mathrm{K}_{2} \mathrm{O} \mathrm{kg}^{-1}$ of the soil.

The irrigation waters with the respective levels of electrical conductivity were prepared by dissolving $\mathrm{NaCl}$ in publicsupply water $\left(E C W=0.30 \mathrm{dS} \mathrm{m}^{-1}\right)$ from the municipality of Pombal-PB, based on the relationship between $\mathrm{ECW}$ and the concentration of salts $\left(\mathrm{mmol}_{\mathrm{c}} \mathrm{L}^{-1}=10 * \mathrm{ECW}-\mathrm{dS} \mathrm{\textrm {m } ^ { - 1 }}\right)$ according to Richards (1954).

Fertilization with phosphorus and nitrogen was performed according to the recommendation of Novais et al. (1991), applying equivalent to $300 \mathrm{mg}$ of $\mathrm{P}_{2} \mathrm{O}_{5}$ and $100 \mathrm{mg}$ of $\mathrm{N} \mathrm{kg}^{-1}$ of the soil, respectively. Monoammonium phosphate, urea and potassium chloride were used as sources of phosphorus, nitrogen and potassium, respectively. The fertilizations were split into 9 portions, which were applied weekly. Micronutrient requirements by cashew were met by biweekly applications of a solution $\left(1.0 \mathrm{~g} \mathrm{~L}^{-1}\right)$ of Ubyfol [(N (15\%); $\mathrm{P}_{2} \mathrm{O}_{5}(15 \%) ; \mathrm{K}_{2} \mathrm{O}(15 \%) ; \mathrm{Ca}(1 \%) ; \mathrm{Mg}(1.4 \%) ; \mathrm{S}(2.7 \%) ;$ Zn (0.5\%); B (0.05\%); Fe (0.5\%); Mn (0.05\%); Cu (0.5\%); Mo $(0.02 \%)]$, sprayed on the adaxial and abaxial sides of the leaves.

\section{Establishment and management of the experiment}

The containers were filled by placing a 2:1:1 proportion of a sandy-textured Entisol, sand and organic matter (welldecomposed bovine manure was used as source), from the rural area of the municipality of São Domingos, PB, whose chemical and physical characteristics were obtained according to the methodology of Donagema et al. (2011): $\mathrm{Ca}^{2+}=2.42 \mathrm{cmol}_{\mathrm{c}} \mathrm{kg}^{-1} ; \mathrm{Mg}^{2+}=5.84 \mathrm{cmol}_{\mathrm{c}} \mathrm{kg}^{-1} ; \mathrm{Na}^{+}=0.09$ $\mathrm{cmol}_{\mathrm{c}} \mathrm{kg}^{-1} ; \mathrm{K}^{+}=0.21 \mathrm{cmol}_{\mathrm{c}} \mathrm{kg}^{-1} ; \mathrm{H}^{+}+\mathrm{Al}^{3+}=0.00 \mathrm{cmol}_{\mathrm{c}} \mathrm{kg}^{-1} ;$ $\mathrm{CEC}=8.56 \mathrm{cmol}_{\mathrm{c}} \mathrm{kg}^{-1}$; organic matter $=3.80 \mathrm{dag} \mathrm{kg}{ }^{-1} ; \mathrm{P}=$ $11.99 \mathrm{mg} \mathrm{kg}$; $\mathrm{pH}$ in water $(1: 2.5)=7.00$; electrical conductivity of the saturation extract $=0.20 \mathrm{dS} \mathrm{m}^{-1}$; sand = $846.3 \mathrm{~g} \mathrm{~kg}^{-1}$; silt $=137.0 \mathrm{~g} \mathrm{~kg}^{-1}$; clay $=16.3 \mathrm{~g} \mathrm{~kg}^{-1}$; moisture at $33.42 \mathrm{kPa}=11.16 \mathrm{dag} \mathrm{\textrm {kg } ^ { - 1 }}$; moisture at $1519.5 \mathrm{kPa}=4.23$ dag $\mathrm{kg}^{-1}$.

Prior to sowing, the soil moisture content was raised to field capacity using the respective water of each treatment. After transplanting, irrigation was performed daily by applying a volume of water sufficient to maintain soil moisture close to field capacity in each container, and the applied volume was determined according to the water requirement of the plants, estimated by water balance: volume applied minus volume drained in the previous irrigation, plus a leaching fraction of 0.10 .

This study used seeds of precocious dwarf cashew, clone 'Embrapa 51', which were planted at $3 \mathrm{~cm}$ depth, by placing one seed per container in the vertical position, i.e. with the thinner end facing down and the peduncle attachment scar facing up.

\section{Traits measured}

Photosynthetic pigments (chlorophyll $a$, chlorophyll $b$ [Chl $a$, $\mathrm{Chl} b$ ] and carotenoids [Car]) and photochemical efficiency were determined at $75 \mathrm{DAS}$, and growth was determined at 25 and 75 DAS. Photochemical efficiency was measured by 
the initial fluorescence (Fo), variable fluorescence (Fv) and maximum fluorescence $(\mathrm{Fm})$ and quantum efficiency of photosystem II (DPSII). Chlorophylls $a$ and $b$ contents ( $\mathrm{mg} \mathrm{g}^{-1}$ of fresh matter - FM) were determined according to the methodology of Arnon (1949), through samples of 5 discs of the blade of the third mature leaf from the apex.

Chlorophyll and carotenoid concentrations were quantified in the solutions using a spectrophotometer at the absorbance (ABS) wavelengths 470, 646, and $663 \mathrm{~nm}$, according to the following equations: Chlorophyll a $(\mathrm{Chl} a)=$ 12.21 $\mathrm{ABS}_{663}-2.81 \mathrm{ABS}_{646}$; Chlorophyll $b(\mathrm{Chl} b)=20.13 \mathrm{~A}_{646}$ - $5.03 \mathrm{ABS}_{663}$; Total carotenoids (Car) $=\left(1000 \mathrm{ABS}_{470}-1.82\right.$ $\mathrm{Chl} a-85.02 \mathrm{Chl} b) / 198$. Chlorophyll $a$ fluorescence was quantified considering fully expanded leaves, using the portable fluorometer Plant Efficiency Analyser - PEA II ${ }^{\circledR}$. The leaves selected for the analysis were pre-adapted to the dark using appropriate clips, and after a period of 30 minutes, the readings were taken.

Plant height was obtained considering as reference the distance from the plant collar to the insertion point of the apical meristem. Stem diameter was measured at $5 \mathrm{~cm}$ from the plant collar, using a digital calliper. Leaf area was obtained by measuring the length and width of all leaves of the plants according to the methodology described by Carneiro et al. (2002), as shown in Eq 1:

$L A=(L \times W) \times f$

$L A=$ Leaf area of the plant $\left(\mathrm{cm}^{2}\right), L=$ leaf length, $W=$ leaf width, and $f=$ equivalent factor $=0.6544$.

\section{Statistical analysis}

After verifying the homogeneity of variances, the obtained data were subjected to analysis of variance by F-test at 0.05 and 0.01 probability levels and in cases of significance, linear and quadratic polynomial regression analysis was performed for the water salinity levels, as well as a means comparison test (Tukey) for potassium doses. When the interaction between factors (SL $x$ KD) was significant, the factor salinity levels was further analysed for each potassium dose, using the statistical program SISVAR-ESAL.

\section{Conclusions}

Water salinity from 0.4 induced reductions in chlorophyll $a$ and $b$ synthesis, maximum and variable fluorescence and growth in sexually propagated precocious dwarf cashew seedlings and increases in carotenoid content and initial chlorophyll fluorescence. However, there was an increase in carotenoid content and chlorophyll initial fluorescence, at 75 days after sowing. Quantum efficiency of photosystem II in cashew plants were decreased sharply with the increment in irrigation water salinity, standing out as indicative of damage to the PSII reaction centres. 'Embrapa 51' precocious dwarf cashew plants can be classified as sensitive to water salinity from $0.4 \mathrm{dS} \mathrm{m}^{-1}$. Potassium doses of 150 and $225 \mathrm{~g} \mathrm{~kg}^{-1}$ soil, corresponding to 100 and $150 \%$ of the recommendation, do not alleviate the effects of salt stress during the precocious dwarf cashew rootstock production phase.

\section{Acknowledgments}

The authors thank the National Council for Scientific and Technological Development (CNPq) and the National Institute of Science and Technology in Salinity (INCTSal) for providing the financial support and the research productivity grant.

\section{References}

Amorim AF, Gomes Filho E, Bezerra MA, Prisco JT, Lacerda CF (2010) Respostas fisiológicas de plantas adultas de cajueiro anão precoce à salinidade. Rev Ciênc Agron. 41:113-121.

Andriolo JL, Janisch DI, Schmitt OJ, Picio MD, Cardoso FL, Erpen L (2010) Doses de potássio e cálcio no crescimento da planta, na produção e na qualidade de frutas do morangueiro em cultivo sem solo. Ciênc Rural. 40:267-272.

Araújo LF de, Lima REM, Costa L de O da, Silveira EM de C, Bezerra MA (2014) Alocação de íons e crescimento de plantas de cajueiro anão-precoce irrigadas com água salina no campo. Rev Bras Eng Agríc Ambiental.18:34-38.

Arnon DI (1949) Copper enzymes in isolated cloroplasts: Polyphenoloxidases in Beta vulgaris. Plant Physiol. 24:115.

Ashraf M, Harris PJC (2013) Photosynthesis under stressful environments: An overview. Photosynthetica. 51:163-190.

Baker NR (2008) Chlorophyll fluorescence: A probe of photosynthesis in vivo. Annu Rev Plant Biol. 59:89-113.

Barros L de M, Cavalcanti JJV, Paiva JR, Crisóstomo JR, Corrêa MPF, Lima AC (2000) Seleção de clones de cajueiro anão para o plantio comercial no Estado do Ceará. Pesq Agropec Bras. 35:2197-2204.

Cakmak I (2005) The role of potassium in alleviating detrimental effects of abiotic stresses in plants. J Plant Nutr Soil Sci.168:521-530.

Carneiro PT, Fernandes PD, Gheyi HR, Soares FAL (2002) Germinação e crescimento inicial de genótipos de cajueiro anão-precoce em condições de salinidade. Rev Bras Eng Agríc Ambiental. 6:199-206.

Dias AS, Lima GS de, Sá FV da S, Gheyi HR, Soares LA dos A, Fernandes PD (2018) Gas exchanges and photochemical efficiency of West Indian cherry cultivated with saline water and potassium fertilization. Rev Bras Eng Agríc Ambiental. 22:628-633.

Donagema GK, Campos DVB de, Calderano SB, Teixeira WG, Viana JHM (Org.) (2011) Manual de métodos de análise de solo. 2. ed. Rio de Janeiro, RJ: Embrapa Solos. 230 p.

Falk J, Munné-Bosch S (2010) Tocochromanol functíons in plants: Antioxidation and beyond. J Exp Bot. 61:1549-1566. Hasanuzzaman M, Bhuyan MMHMB, Nahar K, Hossain MS, Mahmud JA, Hossen MS, Masud AAC, Fujita M (2018) Potassium: A vital regulator of plant responses and tolerance to abiotic stresses. Agronomy. 31:2-29.

Hnilicková H, Hnilikca F, Martinkova J, Kraus K (2017) Effects of salt stress on water status, photosynthesis and chlorophyll fluorescence of rocket. Plant Soil Environ. 63:362-367.

Kalaji HM, Jajoo A, Oukarroum A, Brestic M, Zivcak M, Samborska IA, Cetner MD, tukasik I, Goltsev V, Ladle RJ (2016) Chlorophyll a fluorescence as a tool to monitor physiological status of plants under abiotic stress conditions. Acta Physiol Plant. 38:102-112.

Lima GS de, Dias AS, Souza L de P, Sá FV da S, Gheyi HR, Soares LA dos A (2018) Effects of saline water and potassium fertilization on photosynthetic pigments, growth and production of West Indian Cherry. Rev Ambient Água. 13:e2164.

Malavolta E, Vitti GC, Oliveira AS (1997) Avaliação do estado nutricional das plantas: Princípios e aplicações. Piracicaba: POTAFÓS. 319p. 
Mehta P, Jajoo A, Mathur S, Bharti S (2010) Chlorophyll a fluorescence study revealing effects of high salt stress on photosystem II in wheat leaves. Plant Physiol Biochem. 48:16-20.

Melo HF de, Souza ER de, Cunha JC (2017) Fluorescence of chlorophyll a and photosynthetic pigments in Atriplex nummularia under abiotic stresses. Rev Bras Eng Agríc Ambiental. 21:232-237.

Monteiro DR, Melo HF de, Lins CMT, Dourado PRM, Santos HRB, Souza ER de (2018) Chlorophyll a fluorescence in saccharine sorghum irrigated with saline water. Rev Bras Eng Agríc Ambiental. 22:673-678.

Mostajeran A, Gholaminejad A, Asghari G (2014) Salinity alters curcumin, essential oil and chlorophyll of turmeric (Curcuma longa L.). Res Pharm Sci. 9:49-57.

Nascimento HHC do, Santos CA dos, Freire CS, Silva MA da, Nogueira RJMC (2015) Ajustamento osmótico em mudas de jatobá submetidas à salinidade em meio hidropônico. Rev Árvore. 39:641-653.

Nedjimi B (2014) Effects of salinity on growth, membrane permeability and root hydraulic conductivity in three saltbush species. Biochem Syst Ecol. 52:4-13.

Oliveira VH de (2008) Cashew crop. Rev Bras Frutic.30:1-284.

Pak VA, Nabipour M, Meskarbashee M (2009) Effect of salt stress on chlorophyll content, fluorescence, $\mathrm{Na}^{+}$and $\mathrm{K}^{+}$ ions content in rape plants (Brassica napus L.). Asian J Agric Sci. 3:28-37.

Rabbani ARC, Santos ARF dos, Muniz EN, Lédo AS (2012) Diversidade genética entre cajueiros comerciais. Sci Plena. 6:1-8.

Richards LA (1954) Diagnosis and improvement of saline and alkali soils. Washington: U.S, Department of Agriculture. 160p. Handbook 60.
Santos A de A, Silveira JAG da, Bonifácio A, Rodrigues AC, Figueiredo MDVB (2018) Antioxidant response of cowpea co-inoculated with plant growth-promoting bacteria under salt stress. Braz J Microbiol. 49:513-521.

Shrivastava P, Kumar R (2015) Soil salinity: A serious environmental issue and plant growth promoting bacteria as one of the tools for its alleviation. Saudi J Biol Sci. 22:123-131.

Silva ARA da, Bezerra FML, Lacerda CF de, Sousa CHC de, Chagas KL (2016) Pigmentos fotossintéticos e potencial hídrico foliar em plantas jovens de coqueiro sob estresses hídrico e salino. Rev Agro@mbiente On-line.10:317-325.

Silva EM da, Lima GS de, Gheyi HR, Nobre RG, Sá FV da S, Souza L de P, Soares LA dos A, Fernandes PD (2017) Photosynthetic pigments and photochemical efficiency in soursop under saline water irrigation and nitrogen sources. J Agr Sci. 9:325-334.

Souza L de P, Nobre RG, Gheyi HR, Bonifácio BF, Lima GS de, Fatima RT de, Souza CMA de, Oliveira SG de (2018) Morphophysiology of 'Faga 11' cashew rootstock under saline water irrigation and exogenous proline application. J Agr Sci. 10:402-411.

Taibi K, Taibi F, Abderrahim LA, Ennajah A, Belkhodja M, Mulet JM (2016) Effect of salt stress on growth, chlorophyll content, lipid peroxidation and antioxidant defence systems in Phaseolus vulgaris L. S Afr J Bot. 105:306-312.

Tatagiba SD, Moraes, GABK, Nascimento, KJT; Peloso, AF (2014) Limitações fotossintéticas em folhas de plantas de tomateiro submetidas a crescentes concentrações salinas. Eng Agricult. 22:138-149.

Viégas RA, Silveira JAG da, Lima Junior AR de, Queiroz JE, Fausto MJM (2001) Effects of $\mathrm{NaCl}$-salinity on growth and inorganic solute accumulation in young cashew plants. Rev Bras Eng Agríc Ambiental. 5:216-222. 